\title{
House Prices and Balance of Trade Dynamics in South Africa: Evidence from an Agnostic Identification Procedure
}

Beatrice D. Simo-Kengne, Rangan Gupta, and Goodness C. Aye

\section{Abstract}

In this paper, we analyze the relationship between house prices and the trade balance in South Africa using an agnostic identification procedure. We apply a Bayesian vector autoregression (VAR) to quarterly data from 1979:Q1 to 2011:Q4 and find that 1\% decline in house prices can improve the trade balance by $0.2 \%$. This suggests that house prices represent an additional instrument for trade balance adjustment besides the traditional exchange rate channel. Moreover, the effect of housing demand shock on the exchange rate is short-lived and insignificant; hence, house prices affect the trade balance mainly through the wealth and balance sheet effects on consumption and investment, respectively.

For countries with small foreign assets such as South Africa, the balance of trade is typically the most important component of the current account, and thus, fluctuations in the patterns of trade are key drivers of the current account dynamics. As economies integrate and liberalize, the national current account dynamics remain a policy-relevant issue for both developed and developing countries. Current account dynamics may provide useful information about the supply and demand for domestic currency in the foreign exchange markets and the performance of the domestic economy. In addition, large dispersions of trade deficits trigger worries that a current account reversal could cause a contraction of the real economy as vindicated by the "disorderly correction hypothesis," especially when a current account is mainly driven by consumption. Since trade imbalances are predictive of macroeconomic instability, which is not conducive to sustainable economic growth, it is crucial to understand the sources of these imbalances and their likely adjustment mechanism. Particularly, the role of house prices is of interest and is thus, the focus of this study.

Over the last decade, South Africa's current account deficit has increased sharply from $1.65 \%$ of gross domestic product (GDP) in 1995 to $7.15 \%$ of GDP in 2008. This pattern has borne a relatively close resemblance to the housing market developments, with annual changes in nominal house prices ranging from $-0.13 \%$ to $27.92 \%$ between 1994 and 2011. Smit (2006) points out that the decline in the trade balance is the primary cause of current account deficit in South Africa; hence, indicating the role of consumption in driving current account deficits. This argument is consistent with Kandiero (2007), who emphasized that investment and more importantly consumption goods play a key role in determining South African trade imbalances. Given the strong link between housing 


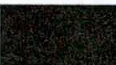

\section{Exhibit 1. House Prices and South Africa's Trade Balance}

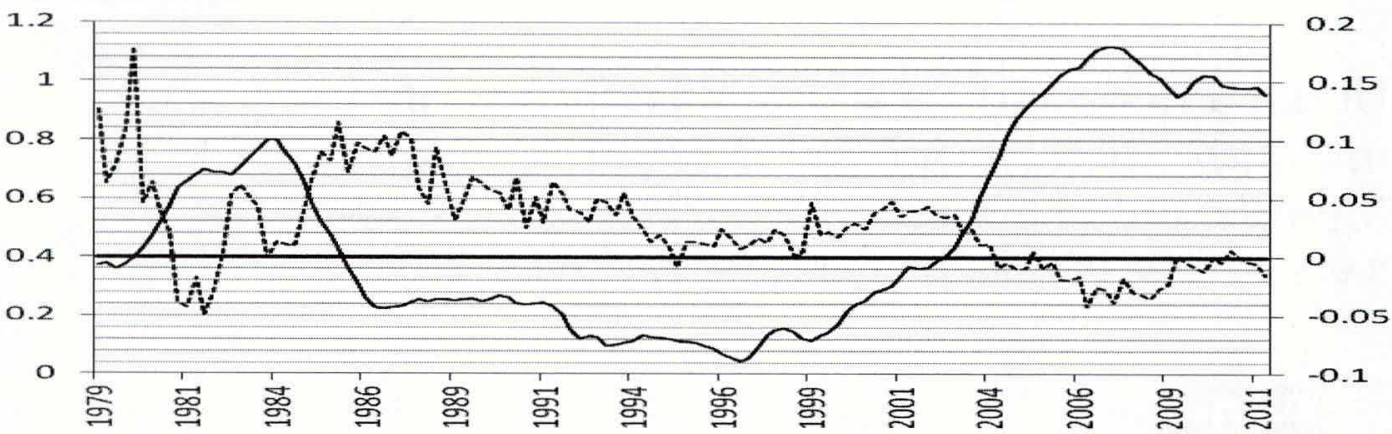

Notes: Real house prices (solid line, scale on the left axis), the ratio of trade balance to GDP (dotted line, scale on the right axis). A zero horizontal line is added from the right axis to indicate the trade deficit.

wealth and consumption spending (Aron and Muellbauer, 2006; Das, Gupta, and Kanda, 2011; Ncube and Ndou, 2011; Peretti, Gupta, and Inglesi-Lotz, 2012; Simo-Kengne, Gupta, and Bittencourt, 2013), we hypothesize and test if house price appreciation could have possibly amplified the vulnerabilities of the trade deficit in South Africa through its effect on consumption.

The current period of trade deficits began in 2004. Over the 33-year sample plotted in Exhibit 1, the trade deficits peak in early 1982 at $4.9 \%$ of GDP. The next larger peak was $4.23 \%$ of GDP in the latter part of 2006. While South Africa ran enormous trade deficits, real house prices were high. This suggests a co-movement between real house prices and the trade deficits, which is consistent with the negative correlation coefficient $(-0.54)$ between the two variables over the sample period. However, in order to derive efficient inference, such relationship needs to be investigated based on an econometric model.

As a leading indicator for the real economy (Gupta and Hartley, 2013), real estate prices facilitate the propagation of boom-bust cycles, which exacerbate the distortions of economic activities (Finicelli, 2007; Schiller, 2007; Aizenman and Jinjarak, 2008). In principle, house price shocks may affect net exports through the wealth effect and/or collateral effect, as well as the exchange rate channel (Fratzscher, Juvenal, and Sarno, 2010; Gete, 2010; Laibson and Mollerstrom, 2010; Bergin, 2011). The wealth effect implies that house price fluctuations induce an adjustment of consumption and investment decisions, which will be reflected as a trade surplus or deficit. Based on the permanent income hypothesis, an increase in house prices raises the expected income of households and thus consumption, while also serving as collateral, making it easier for firms to finance investment opportunities. These might lead to increases in import, thus inducing a deterioration of the country's trade balance. On the other hand, real exchange rate determines net exports through relative prices and, plausibly, a wealth effect, the sign of which would depend upon the currency denomination of assets held by domestic investors relative to the weight of foreign goods in the consumption basket (Gavin, 1989). Under the assumption that exchange rate policies can be separated from monetary 
policies, the increase in house prices may be favorable to the exchange rate appreciation, which affects international competitiveness, resulting in a deterioration of the trade balance. However, exchange rate might not be an efficient tool to adjust trade balance in open economies (McKinnon, 1990; McKinnon and Ohno, 1997). ${ }^{1}$ Further, Yang and Zhiqiang (2012) find that the impact of higher house prices on the exchange rate is negative in the short run and positive in the long run, resulting in an ambiguous link between housing wealth and the exchange rate.

Although a number of researchers have attempted to analyze the determinants of the current account fluctuations, ${ }^{2}$ only a few have assessed the contribution of house price shocks to the emergence of external imbalances. Notable and recent exceptions include Punzi (2007), Aizenman and Jinjarak (2008), Kole and Martin (2009), Fratzscher, Juvenal, and Sarno, (2010), Gete (2010), Laibson and Mollerstrom (2010), Adam and Kuang (2011), and Bergin (2011). The common result from these studies points to the positive effect of house price appreciation on the current account deficits. However, the magnitude of the effect varies depending upon the methodology used. Thus, the observed differences in the response of a current account to house price shock may be due to methodological flaws. Further, most of these studies focus on cross-country analysis, which admittedly offer more degrees of freedom but do not provide a structural identification of house price shocks. Additionally, the cross-country heterogeneities in the housing markets, trade openness, and financial market depth with possibly different structures of the current account, require country-specific analysis of the relationship between house prices and current account dynamics.

Despite the important implications that house price shocks may have on external imbalances, to the best of our knowledge, there no one has examined this link in South Africa where housing accounts for $29.40 \%$ of households' assets and $21.68 \%$ of total wealth (Das, Gupta, and Kanda, 2011). Moreover, as indicted earlier, strong housing cycles have been over-riding features of the South African housing market since the second half of 1990s. In fact, emerging economies such as South Africa are subject to both domestic and foreign shocks, ${ }^{3}$ resulting in large capital movements, as well as interest and exchange rates fluctuations with sizeable effects on asset (including housing) prices which, in turn, affect the current account positions through the wealth and/or balance sheet effects on consumption and investment, respectively. We, therefore, extend the literature by investigating the effect of house price shocks on trade balance in South Africa using a Bayesian vector autoregressive (VAR) approach with sign restrictions on the impulse response functions. This methodology has been applied by Fratzscher and Straub (2009) and Fratzscher, Juvenal, and Sarno (2010) in the context of the identification of stock and house price shocks based on Uhlig's (2005) pure sign restrictions. Alternatively, the restrictions may also be derived from a structural model, as in Adam and Kuang (2011). ${ }^{4}$ To identify all the shocks properly, structural models require many restrictions. For instance, the identification of eight structural shocks in an eight-variable VAR, as we use, requires as many as $(8 \times 7) / 2=28$ restrictions. Since we want to identify a housing demand shock only, we rely upon the sign restriction scheme, which helps us achieve our objective without requiring us to identify the other shocks in the system. The identification of a housing demand shock, using the sign restriction procedure, offers several advantages (Busch, Scharnagl, and Scheithauer, 2010; Andre, 
Gupta, and Kanda, 2012). First, it has the advantage of distinguishing housing demand shock from other types of shocks including aggregate demand, monetary policy, and fiscal policy shocks, which could yield similar behavior of the variables in the system. Second, it prevents theoretically inconsistent behavior of the impulse responses commonly observed in the popular recursive (i.e., Cholesky) identification scheme. ${ }^{5}$ Third, given that the structural identification is based on orthogonalized matrices drawn randomly within a Bayesian framework, the ordering of the variables in the VAR does not affect the impulse responses. Indeed, it allows immediate responses to the relevant shock, thus mitigating the issue of delayed effects.

We employ eight variables in our VAR model. Besides standard variables such as private consumption, price level, short-term interest rate, and real effective exchange rate, we include the key variables of interest, namely real house prices and the ratio of trade balance to GDP. Given that housing is not only a consumption good but also represents an alternative to investment in stocks, we further add mortgage loans and residential investment in order to control for balance sheet effects on investment over the relevant time horizon. In addition to carrying out impulse response analysis following a housing demand shock, we also analyze the historical decomposition of the impulse responses, which, in turn, adds a dynamic, medium-term oriented perspective to the on-going policydriven debate of current account imbalances.

There are two specific assumptions regarding the structural interpretation of the asset price shocks in the literature, which we employ in our study. The first hypothesis is consistent with Engle and Rogers (2006) in that house prices are considered to be forward looking and thus reflect people's expectations about future outcomes, such as economic fundamentals. For instance, a positive house price shock may be understood as being an increase in expected future productivity, which leads to a rise in house prices. The second hypothesis associates the sharp increase in house prices to some extent with rational bubbles, as in Kraay and Ventura (2005). Consistent with rational expectations, shifts in people's expectations and/or rational bubbles, which are directly reflected in higher house prices, would thus be favorable to current account deficits.

The rest of the paper is organized as follows. Empirical methodology is briefly presented. Data and empirical results are discussed next. Finally, the paper closes with concluding remarks.

\section{Empirical Methodology}

In line with Uhlig (2005), we implement the sign restrictions approach in a Bayesian VAR framework for estimation and inference of the following reduced-form VAR:

$$
\begin{aligned}
& Y_{t}=A_{1} Y_{t-1}+A_{2} Y_{t-2}+\ldots+A_{p} Y_{t-p}+u_{t} \\
& u_{t} \sim N(0, \Sigma),
\end{aligned}
$$

where $Y_{t}$ is an $n \times 1$ vector of endogenous variables at time $t=1, \ldots, T$, and including consumer price level $(p)$, private consumption $(c)$, residential investment $(r i)$, the interest rate $(i)$, real house prices $(b p)$, mortgage loan $(l)$, the real effective exchange rate (reer), and trade balance $(t b)$. 


$$
Y=[p, c, r i, i, b p, l, \text { reer }, t b]
$$

$A_{i}$ are coefficient matrices of size $n \times n$ and $u_{t}$ is an $n \times 1$ vector of residuals, with variancecovariance matrix $E\left[u_{t} u_{t}^{\prime}\right]=\Sigma$. The reduced-form residuals $u_{t}$ have no structural interpretation. To make structural inferences from the data, sufficient restrictions need to be provided in order to identify the VAR in equation (1). The identification of the VAR in (1) requires a matrix $B$ such that $B \varepsilon_{t}=u_{t}$, where the coefficient $b_{i j}$ captures the contemporaneous response of the $i^{t h}$ endogenous variable in the system to the $j^{t h}$ structural shock of one standard deviation.

Conventionally, the identification is achieved by orthogonalizing the reduced-form disturbances using the Cholesky decomposition. Accordingly, a recursive structure is imposed on $B$ so that $B$ is restricted to be a lower triangular. However, without a priori theorizing, this method often leads to counterintuitive behavior of some variables under consideration (Uhlig, 2005). Thus, our empirical investigation relies on pure-sign restriction procedure developed by Uhlig (2005), which basically imposes theoretically consistent restrictions on some variables for a specific period of time, and hence, ensures expected behavior of variables with respect to the theory.

We seek to identify housing demand shocks. ${ }^{6}$ For this purpose, we first analyzed the impulse response functions from a recursive causal ordering of variables, as indicated in equation (2). As in Musso, Neri, and Stracca (2011), equation (2) is interpreted as a housing demand function since it relates real house prices to consumption and residential investment. On the other hand, the ordering of variables is in line with Jarocinski and Smets (2008), Iacoviello and Neri (2010), and Musso, Neri, and Stracca (2011), who associate a positive non-monetary housing demand shock with an increase in house prices, which leads to a rise in residential investment without causing a fall in the monetary policy instrument. Further, consumption is assumed not to react simultaneously to this shock. Hence, residential investment, interest rate, and real house prices are ordered after consumer price level and private consumption. Finally, under the assumption that trade balance responds to changes in all other variables, trade balance is ordered last, after mortgage loan and the real effective exchange rate. Although these features might help to identify a housing demand shock, it is widely recognized that one cannot separate a housing demand shock from macroeconomic shocks (such as technology, monetary, and fiscal policy shocks) based on a standard VAR (e.g., AspachsBracons and Rabanal, 2011; Musso, Neri, and Stracca, 2011). Further, as indicated in Berg (2011), the ordering of financial variables is unclear, although his findings appear to be robust to different ordering schemes. Moreover, as will be seen below, the results from this identification scheme are inconsistent with theoretical considerations, thus motivating the use of an alternative identification procedure.

We summarize our identification sign restrictions in Exhibit 2. To ensure that house price shock is a housing demand shock, we make use of an agnostic identification scheme by imposing sign restrictions on the responses of all variables in the VAR except $t b$ (our variable of interest) and reer (given the uncertainty in the exchange rate-house price relationship). Albeit the wealth effect has been investigated empirically in South Africa, ${ }^{7}$ there is no study that relates house prices and exchange rate in this specific context. Additionally, the exchange rate channel might not be significant for a small open economy 


\section{Exhibit 2. Identifying Sign Restrictions}

\begin{tabular}{|c|c|c|c|c|c|c|c|}
\hline Shock & $p$ & $c$ & ri & $i$ & $h p$ & $I$ & reer \\
\hline Housing demand & + & + & + & + & + & + & \\
\hline
\end{tabular}

such as South Africa, since exchange rate movements are related to the degree of trade openness of an economy (Hau, 2002). In this respect, we keep reer unrestricted, allowing "the data to speak," and impose non-negative sign restrictions on $c, i, p, l, b p$, and $r i$ for four quarters. These reactions of the macroeconomic variables are fundamentally different from the responses that could originate from an aggregate demand, aggregate supply, monetary policy, and credit shocks. A standard aggregate demand disturbance can either originate from an exogenous shock to consumption, residential investment or the trade balance itself. The shock to the real effective exchange rate could also be viewed as an aggregate demand shock, since it will affect the aggregate demand via net exports (trade balance). While a positive housing demand shock induces an increase in house prices (see sign restrictions in Exhibit 2), a positive aggregate demand shock results in inflationary pressure to which monetary authority may react by raising the interest rate. As interest rate increases, the cost of financing real estate project increases, leading to a fall in housing demand and hence a decline in real house prices. Theoretically, the monetary policy shock is different from the aggregate demand shock, as well as the housing demand shock, since we would expect inflation to fall following a contractionary monetary policy shock.

An exogenous positive shock to the mortgage loans, characterizing a credit shock, is likely to originate from a fall in the mortgage rate, which is only possible if the interest rate declines, causing house price, consumption, and residential investment to rise with possible inflationary effects. Again, the movement of the interest rate distinguishes this shock from the aggregate demand and housing demand shock. Finally, with no measure of output in the model, the CPI shock captures the aggregate supply side of the model. A positive shock to the CPI is likely to lead to an increase interest rate, but most likely will be associated with a fall in consumption, investment, and house price (and hence mortgage loans), since the economy in general is costlier. Note that, there could be a hedging effect of inflation on house prices (Gupta and Inglesi-Lotz, forthcoming), which could lead to an increase in house prices and can have a positive impact on consumption. However, it is possible that the direct effect of higher general prices is likely to reduce consumption more than the increase in the same through the hedging effect. ${ }^{8}$ Clearly, our identification of the housing demand shock in this framework is unique.?

As mentioned earlier, one major attraction of the sign restrictions-based identification procedure is the possibility to distinguish one particular shock from the others. Paustian (2007) pointed out that the effectiveness of this identification procedure in delivering the unambiguous and correct sign of unconstrained impulse responses depends on the number of shocks identified; the larger the number of structural shocks, the closer to the 
true impulse responses of the shock of interest. However, he admitted that since the evaluation was based on the numerical analysis of calibrated DSGE model, the result depends on the underlying model structure and therefore cannot be generalized to other models. Our objective is to analyze how trade balance evolves following a housing demand shock, that is, to tract the dynamic path of the wealth and balance sheet effects in the process and their significance over time. We thus identify only one shock (housing demand shock) at the expense of a greater share of the structural shock remaining unexplained (Uhlig, 2005). Without making a compromise on the identification of the housing demand shock, the focus on the shock of interest is in line with recent studies on wealth effects-based VAR models with sign restrictions identification procedures (e.g., Fratzscher and Straub, 2009; Fratzscher, Juvenal, and Sarno, 2010; Andre, Gupta, and Kanda, 2012).

As well documented in the recent literature (e.g., Fry and Pagan, 2011), the sign restrictions scheme will not yield unique identification. Explicitly, although this identification procedure resolves the structural identification problem by providing adequate information to identify the structural parameters, many models with identified parameters might provide the same fit to the data. As a result, the estimated impulse response functions characterize the responses to shocks from different models, suggesting that the structural shocks may not be orthogonal (Aastveit, Bjørnland, and Thorsrud, 2012). In our case, however, we identify only one shock, not multiple shocks. In addition, as discussed above, theoretically all the different shocks are expected to have different effects on the variables of the economy (and hence sign restrictions), which in turn, explicitly allows us to distinguish the housing demand shock from other shocks, since impulse responses that do not conform with theory are discarded in any case.$^{10}$ So in our case, the median response is unique. More importantly, we allow the sign-restrictions to hold for four quarters, not just one quarter. Hence, as discussed in Fry and Pagan (2011), the introduction of extra information this way enables us to discriminate between the multiple models. It is believed that adding sign restrictions for longer impulse responses provides stronger identifying information, as depicted by the Monte Carlo study in Paustian (2007).

\section{Data and Results}

\section{Data}

Included in this sample study are private consumption, consumer price index, money market rate, residential investment, mortgage loan, real house price index, real effective exchange rate, and trade balance relative to GDP. The data sample covers quarterly series for the period of 1979:01 to 2011:04. Although other variables are available prior to 1979, the choice of the dataset is constrained by the availability of the mortgage loan data, which determines the starting point of the empirical investigation. Barring the money market rate and consumer price index, which are derived from the International Financial Statistics of the International Monetary Fund, and the seasonally-adjusted house price index obtained from Amalgamated Bank of South Africa (ABSA), the remaining variables were obtained from the Quarterly Bulletin of the South African Reserve Bank (SARB). We aggregated monthly house prices index to get quarterly frequency. 
In South Africa, banks are responsible for more than $90 \%$ of mortgage lending, making the banking sector the most important provider of mortgage financing for housing. ${ }^{11}$ ABSA, one of the major private banks in South Africa, plays a leading role in the mortgage finance market and represents one of the most well-known sources of residential property market data in the country. It categorizes the South African housing market into three price segments: luxury (ZAR 3.5 million-ZAR 12.8 million), middle (ZAR 480,000-ZAR 3.5 million), and affordable (below ZAR 480,000 and area between 40 square meters-79 square meters). The middle-segment is further categorized into three more segments based on size: large-middle (221 square meters- 400 square meters), medium-middle (141 square meters-220 square meters), and small-middle (80 square meters-140 square meters). Since we are concerned about the entire economy in general, we decided to use the house prices of the entire middle segment in our analysis, as it is likely to be the house prices that apply to the most households. Note that, to compile these indices, ABSA follows a specific process. First, data are extracted from applications for mortgage financing that were approved by the bank. These data include purchase prices, building and land area, and building and land value, among others, are generated and filtered for the different size categories. Cut-off prices for the affordable, middle, and luxury segments are determined once a year based on various trends, such as the CPI inflation and growth in housing prices. These series are then seasonally adjusted and smoothed and the average house prices data series are compiled for each segment. For the sub-segments (small, medium, and large), the weighted average is combined based on the sample size of each segments. ${ }^{12}$

The variables are used in levels as it is standard that Bayesian analysis does not require stationarity of the data. As indicated by Sims, Stock, and Watson (1990), a Bayesian approach relies on the likelihood function, which keeps the same Gaussian distribution irrespective of the presence of unit roots. The estimation is based on two lags, as suggested by the Schwartz information criterion.

We start off by discussing the results from the recursive identification procedure, which provides theoretically inconsistent responses of some variables, thus motivating the decision to rely on the results from the sign-restriction methodology.

\section{Impulse Responses Using a Recursive Identification Scheme}

Exhibit 3 reveals that a housing demand shock of one standard deviation generally shows the expected behavior for all variables except the consumer price index. Real house prices increase by $0.04 \mathrm{bps}$, staying significant for about 17 quarters followed by a very slow reversion to the baseline over 8 quarters. This pattern is consistent with significant autocorrelation in house prices that may result from extrapolative expectations (Andre, Gupta, and Kanda, 2012). Higher housing demand leads to long-lasting increases in residential investment and mortgage loans associated with positive reactions of the private consumption and interest rate, which last about 9 and 6 quarters, respectively. The response of the trade balance looks conventional (significant decline) and the timing of the response matches that of the nominal interest rate and private consumption. However, real effective exchange rate increases initially by $0.7 \%$, then reversing course within 3 quarters, although the decrease is not significant. This feature seems to be in line with the ambiguity found in the correlation between house prices and the exchange 


\section{Exhibit 3. Impulse Responses with Recursive (Choleski) Identification Scheme}

Impulse Responses for CPI

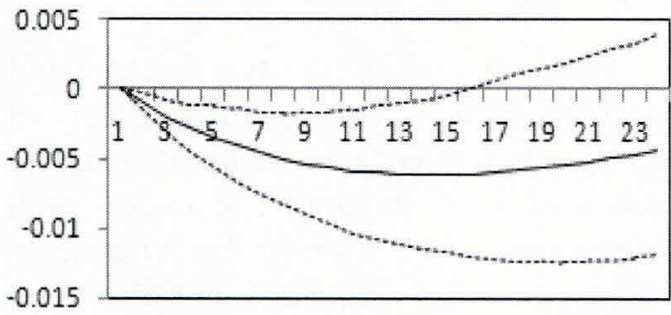

Impulse Responses for Pvt Consumption

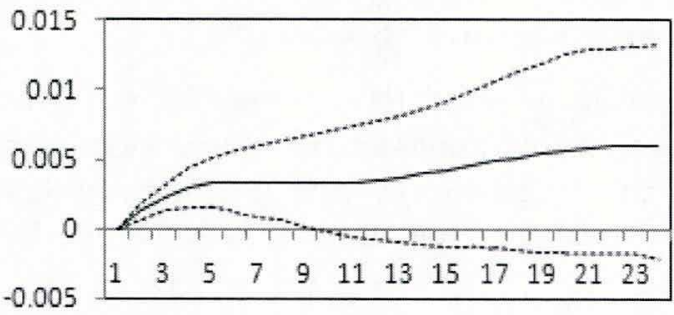

Impulse Responses for Resid Investment

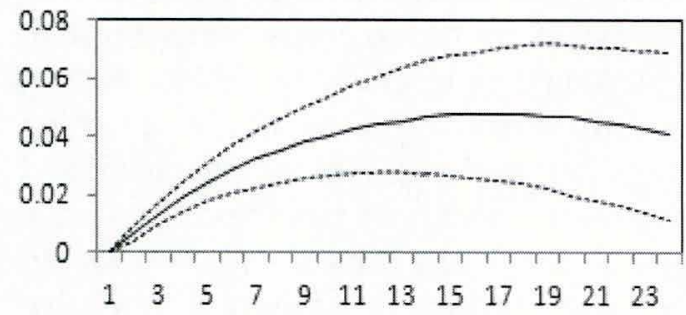

Impulse Responses for Nominal Interest Rate

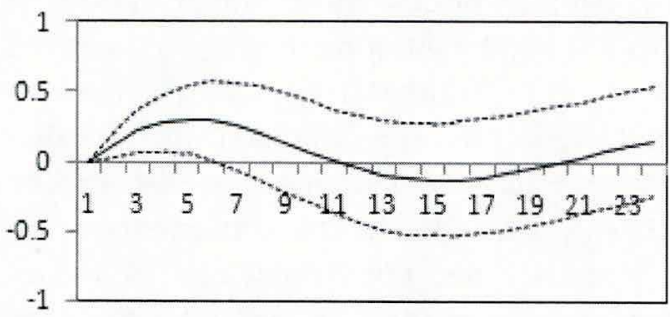

Impulse Responses for Real House Prices

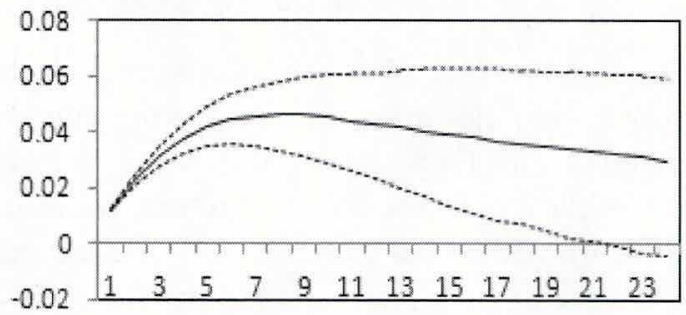

Impulse Responses for Mortgage Loan

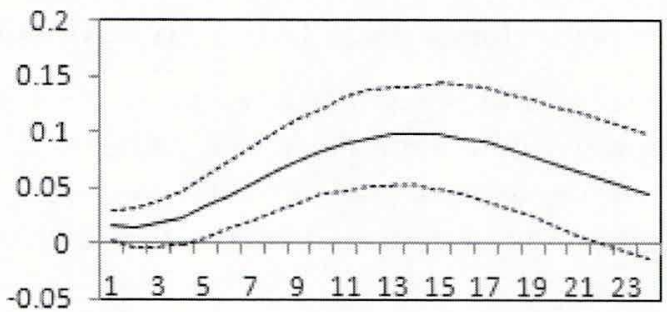

Impulse Responses for Real Eff. Exchange Rate

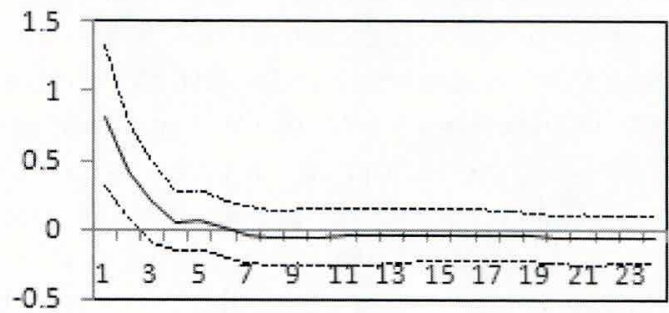

Impulse Responses for Trade Balance

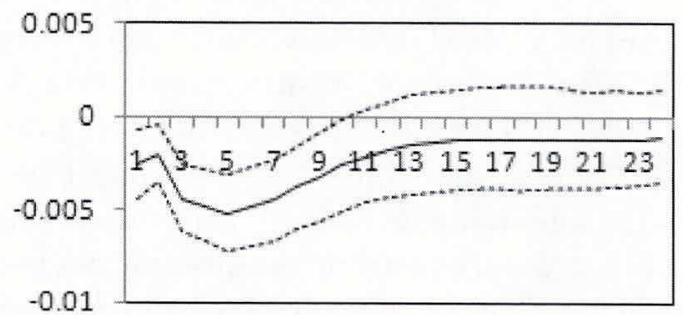

Note: The solid line represents the median, while the dotted lines indicate the $16 \%$ and the $84 \%$ quantiles for the sample of impulse responses. 
rate, suggesting the irrelevance of the exchange rate channel. Further, a long-lasting decrease in the level of consumer prices, which is hardly compatible with a housing demand shock, confirms the version of "price puzzle" mentioned above. This puzzling effect appears significant for 14 quarters, corroborating the theoretical inconsistencies that yield the recursive identification procedure.

Despite the lack of a Choleski decomposition to properly identify the housing demand shock, one can infer that a housing shock may affect the trade balance through several mechanisms. First, the significant rise in residential investment generates multiplier effects on employment and income, which result in a deterioration of the trade balance. Second, as mortgage loans increase, the wealth and/or collateral effects justify the increase in private consumption, which in turn induces an increase in trade deficits. Third, increases in interest rates and real effective exchange rate could offset part of the investment and wealth effects, leading to the observed short-lived reaction of the trade balance.

\section{Impulse Responses Using an Agnostic Identification Procedure}

Due to the unexpected decrease in the consumer price level within a recursive identification framework, we have used an alternative approach to better identify a housing demand shock. This procedure is called agnostic in that we impose sign restrictions to some variables, allowing impulse response functions to be theoretically consistent.

Exhibit 4 displays the responses to a one standard deviation in real house prices corresponding to the $16 \%$ and $84 \%$ quantiles from 100 bps. A higher housing demand shock raises house prices by more than $0.01 \%$ initially. The rise in house prices is followed by a significant increase (from 5 to 14 quarters) in mortgage loans, consumption, residential investment, and consumer prices, suggesting the presence of wealth/collateral and balance sheet effects on consumption and investment, respectively. The puzzling effects reported above are avoided by construction. Moreover, besides the significant and immediate response of mortgage loans, which satisfies a necessary condition to identify a housing demand shock (Andre, Gupta, and Kanda, 2011), one can distinguish between housing demand shock and aggregate demand shock since the former induces a positive correlation between consumption and the consumer price level, while the latter is typically associated with a negative correlation between the two variables. Further, in response to the increase in consumption and consumer prices, the monetary policy is tightening. Short-term interest rates show a significant and long-lasting increase, consistent with the Taylor-type feedback rule in the reaction of the South African Reserve Bank to a financial condition index, which included real house prices, as depicted in Naraidoo and Raputsoane (2010) and Naraidoo and Ndahiriwe (2012). This result is also in line with Simo-Kengne, Gupta, and Bittencourt (2013), who document the existence of positive feedback from the housing sector to interest rates, confirming that monetary policy does react to house price shock in South Africa. We observe an initial depreciation of the real effective exchange rate, followed by a noticeable appreciation up to two quarters and a near to zero effect thereafter; however, the effect is not significant. This again substantiates the uncertainty surrounding the effect of housing wealth on domestic currency. 


\section{Exhibit 4. Impulse Responses with Sign Restrictions}
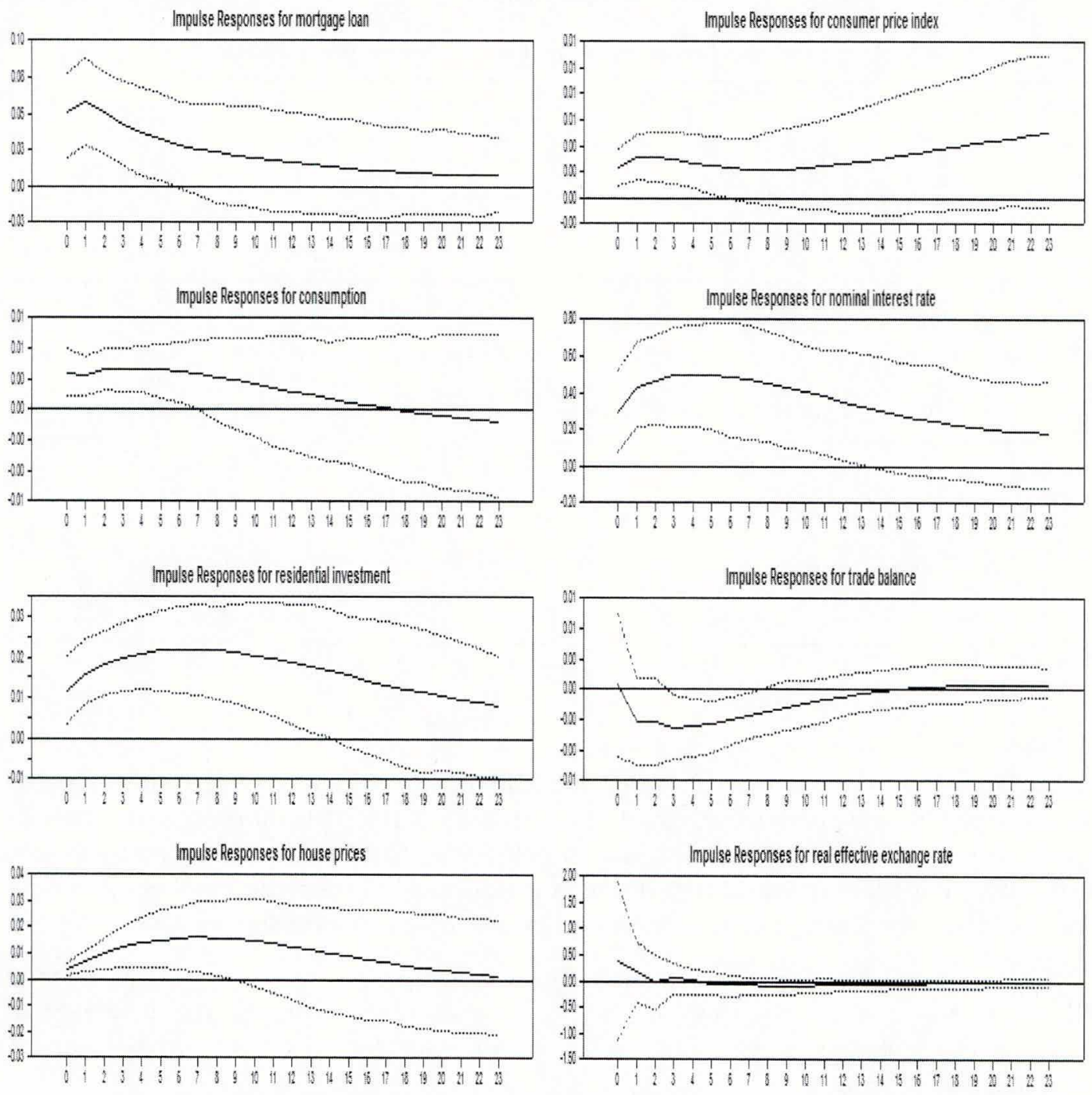

Note: The solid line represents the median, while the dotted lines indicate the $16 \%$ and the $84 \%$ quantiles for the sample of impulse responses.

Finally, in response to house price growth, the trade account worsens immediately and reaches a trough around 3 quarters. Thereafter, the trade deficit improves gradually and trade balance is restored around 4 years. However, the effect is only significant between the 3 and 8 quarters. The maximum impact of one standard deviation corresponding to $1.23 \%$ increase in house prices on the trade balance is about $-0.25 \%$. It can therefore be economically inferred that a $10 \%$ increase in house prices corresponds to the deterioration of the trade balance by $2.02 \%$. This result is in line with Fratzscher, Juvenal, and Sarno (2010) who associate a $1.6 \%$ deterioration of the U.S. trade balance with $10 \%$ increase in 


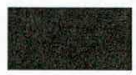

Exhibit 5. Forecast Error Variance Decomposition under a Pure Sign Restriction Approach

Fraction of trade balance due to a house price shock

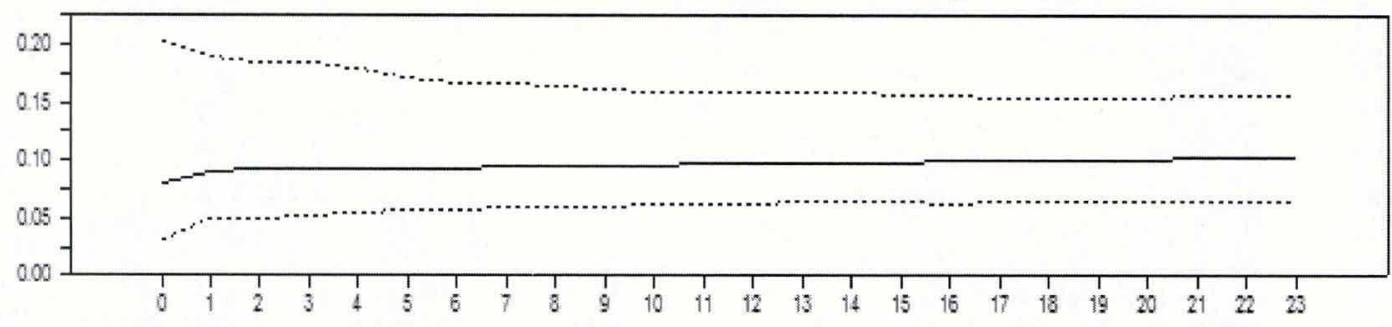

Fraction of real effective exchange rate due to a house price shock

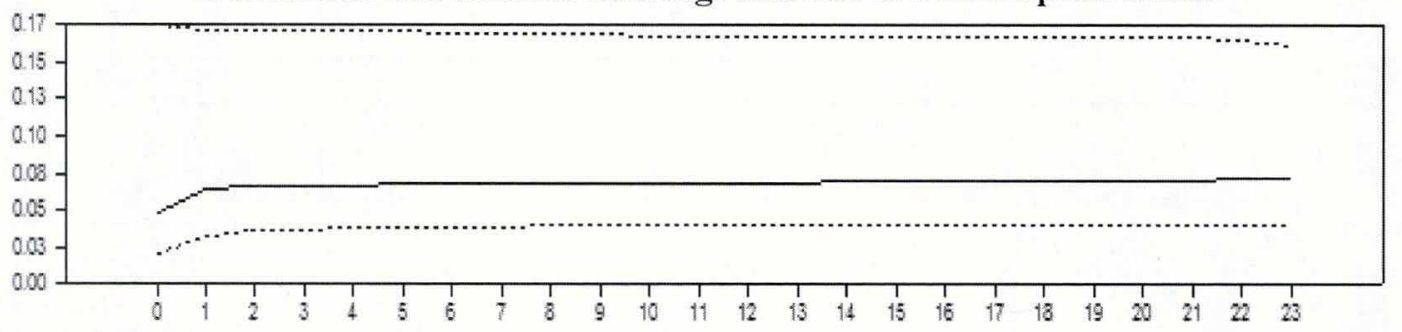

house prices after 11 quarters. However, our findings are of greater magnitude compared to those reported by Fratzscher, Juvenal, and Sarno (2010). This difference may be due to the advantage of identifying only one shock (Uhlig, 2005). As highlighted by Busch, Scharnagl, and Scheithauer (2010), there is a trade-off between the number of shocks identified and the fraction of structural shocks that remains unexplained.

Without a priori theorizing, it appears difficult to properly identify a housing demand shock. The pure-sign restriction impulse responses have mitigated the evidence of puzzling effect observed with the consumer price level in the benchmark recursive identification scheme.

\section{How Much Variation in the Trade Balance Do House Price Shocks Explain?}

The importance of the house price shocks in explaining fluctuations in the trade balance is evaluated by examining both variance decomposition and historical decomposition. ${ }^{13}$ The variance decomposition shows the fraction of forecast error variance for the trade balance that is attributable to innovations in house prices. It captures both direct and indirect effects and can be interpreted, according to Sims (1982), as a Granger-causal relation. Exhibit 5 displays the variance decomposition of the relevant variables (unrestricted variables). The plots indicate that housing demand shocks account for $8 \%$ $(7 \%)$ in the total variation in trade balance (real effective exchange rate) after one quarter. As the horizon increases, these proportions increase and reach about $10 \%$ and $8 \%$, respectively, after 20 quarters. However, this econometric tool provides only the overall effect and does not allow analyzing the relative importance of house price shocks across 


\section{Exhibit 6. Historical Decomposition with a Pure Sign Restriction Approach}

\section{Contribution of house price shock to trade balance}

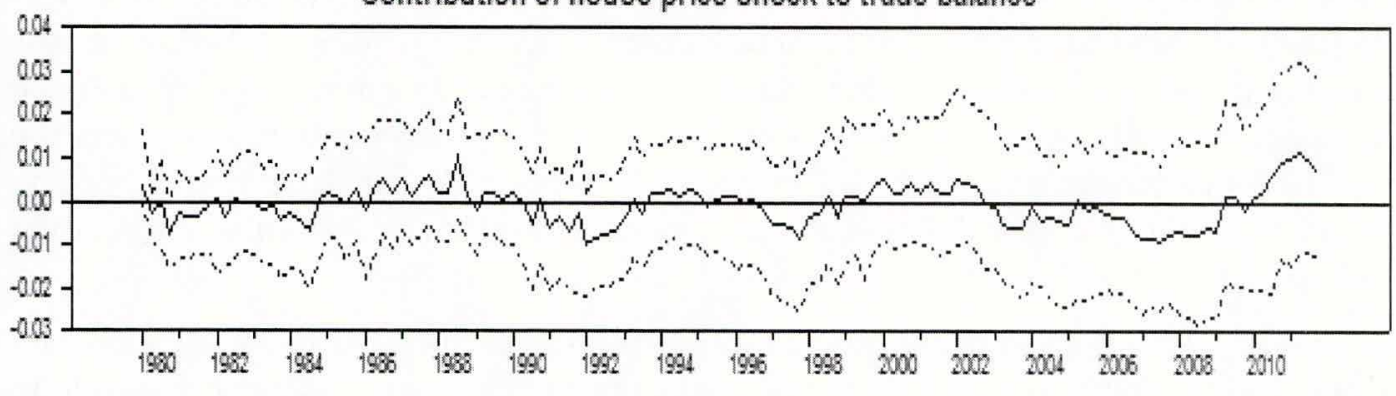

Contribution of house price shock to real effective exchange rate

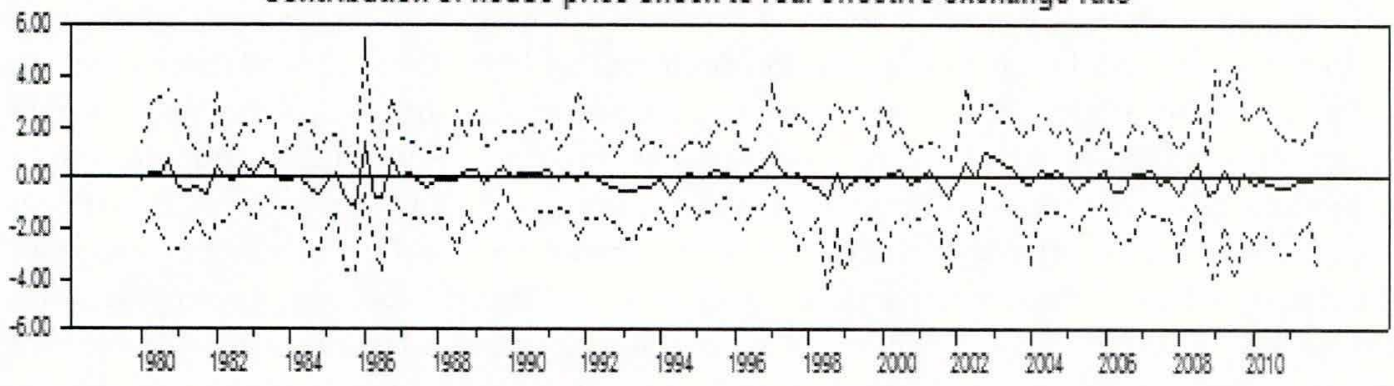

different sub-periods. Therefore, we conduct a historical decomposition in order to appreciate how such effect has evolved over time.

The historical decomposition depicts the cumulative effect of a particular shock for a given date. In Exhibit 6, we plot the contribution of housing demand shocks to the historical path of the trade balance and real effective exchange rate over the sample period. While the evolution of the role of house price shocks on the real effective exchange rate seems constant over time, trade balance appears to have been subject to several shocks of different magnitude throughout the relevant period, most notably in the 1980s, 1990s, and 2000s. These three sub-periods coincide with some important domestic and foreign shocks, which may have affected housing activities. As shown in Exhibit 6, the gap between the forecast (dashed lines) and the true effect (solid line) is particularly large in the third sub-period, indicating a smaller incidence of house price shock on trade deficit than could have predicted from the model during that period.

The 1980s sub-period coincides with the gold price boom and the beginning of financial liberalization, which may have contributed to the run-up in house prices. The resulting wealth and collateral effects led to a consumption boom, which translated into a trade deficit. The subsequent recovery of the trade balance observed between 1985 and 1989 can be attributed to the slowdown in house prices due to political pressures and the uncertainty about the future of the country with a negative effect on people's confidence. The sub-period of 1990s shows substantial troughs and slower recoveries in the trade balance compared to the 1980 s sub-period. This could be ascribed to the combined 
effects of a positive domestic shock (political transition, higher economic growth, as well as low inflation and interest rate) and a negative world shock (Asian crisis). The last decade indicates a smaller trade deficit attributable to house price shocks compared to the 1990 s sub-period. However, a substantial improvement is observed since 2010. This is quite understandable since the monetary transmission mechanism in the last decade has shifted somewhat to the housing sector, enabling monetary authorities to restrain the unexpected effects of housing wealth on the macroeconomic stability. Moreover, the 2007-2009 global financial crisis and its contagion worldwide may have hit the housing sector, leading to the slowdown of the general economy, which in turn resulted in the trade balance appreciation.

In summary, high house price growth induced by financial liberalization, loose monetary policy, and to some extent world shocks turns out to have played an important role in driving South African trade deficits. More specifically, the increase in house prices encouraged lenders to extend loans to borrowers, allowing households to increase their investment expenditure and consumption spending on both domestic and foreign goods, resulting in the trade balance deterioration. According to the data, a housing market underperformance of $10 \%$ improves the trade balance by about $2.02 \%$. The adjustment happens gradually, taking around four years. From a policy perspective, this result suggests that house price movements are a potential driver of the adjustment process of the trade balance, thus making house prices an additional tool for current account adjustment in South Africa. Since the decline in house prices is favorable to trade balance appreciation, it is likely that South African Reserve Bank (SARB) responds significantly to house price inflation to limit the consumption spending and/or borrowing capacity of households, which improves individual saving and hence the trade balance. The policy relevance of the house price channel is further demonstrated by the common observation that the SARB does react to house price shocks (Ncube and Ndou, 2011; Peretti, Gupta, and Inglesi-Lotz, 2012; and Simo-Kengne, Gupta, and Bittencourt, 2013).

\section{Conclusion}

Given the on-going global debate on the causes of global current account imbalances, we provide empirical evidence of the effect of house price shocks on the current account balance in South Africa. In order to clearly identify a housing demand shock and also to avoid possible puzzling results frequently observed when shocks are identified using a Choleski (recursive) identification scheme, housing demand shock was identified using sign restrictions. This is implemented within a Bayesian VAR framework employing eight variables: consumer price index, private consumption, residential investment, nominal interest rate, real house prices, mortgage loans, trade balance, and the real effective exchange rate. As in Uhlig (2005), we impose theoretically consistent non negative sign restrictions on the responses of real house prices, private consumption, consumer price index, nominal interest rate, residential investment, and mortgage loans and keep unrestricted the variables of interest, namely trade balance and the real effective exchange rate. 
The results show that higher housing demand tends to deteriorate the trade balance. A $1.23 \%$ increase in house prices worsens the trade balance by $0.25 \%$ at a horizon of three quarters. However, the effect on the real effective exchange rate is short-lived and insignificant. This suggests that wealth and/or collateral and balance sheet effects on private consumption and investment, respectively, represent the main channel through which the South African housing market spills over onto the current account balance. Further, the relative contribution of housing demand shocks to trade deficit is found to vary over time. As expected, the smaller fraction is reported in the 2000s, possibly substantiating the effectiveness in the conduct of South African monetary policy, which is currently encompassing house price movements in its interest rate setting behavior.

\section{Appendix}

\section{Implementation of the BVARs (Choleski Decomposition and Sign- Restriction Approach)}

The Choleski factorization is applied within a Bayesian framework by imposing a diffuse (Jeffrey's) prior on the VAR (i.e., $F(A, \Sigma) a|\Sigma|^{-(n+1) / 2}$, the posterior being essentially the ordinary least squares estimates. The impulse responses are thus generated from a Monte Carlo simulation with 1,000 keeping draws. Specifically, we use antithetic acceleration, which consists of drawing new values of $\Sigma$ and $A$ on the odd draws and then flipping $A$ around the mean of the posterior on the even draws.

Differently from the Choleski decomposition where alternative orderings of the variables generally lead to different impulse responses, by imposing sign restrictions on the impulse responses of a set of variables, Uhlig (2005) showed that any orthogonal matrix $Q$ with $Q Q^{\prime}=I_{n}$ and $\Sigma=B Q Q^{\prime} B^{\prime}$ is an admissible decomposition for $\Sigma$, in which case $u_{t}=$ $B Q \tilde{\varepsilon}_{t}, E\left[\tilde{\varepsilon}_{t} \tilde{\varepsilon}_{t}^{\prime}\right]=I_{n}$. Although different $Q$-matrices produce different signs and magnitudes of the impulse responses, it is not possible to discriminate among them on the basis of data, as they imply identical VAR specifications. Thus, for any impulse vector $b \in \boldsymbol{R}^{n}$ such that $b=\tilde{B} q$ and $\tilde{B} \tilde{B}^{\prime}=\Sigma, \tilde{B}$ is the lower triangular Choleski factor of $\Sigma$. For a given structural vector $b_{j}$, the impulse responses of $n$ variables up to $K$ horizons can be computed using the estimated coefficients $A_{i}$ as follows:

$$
I R_{k}=[I-A]^{-1} b_{j}
$$

where $I R_{k}$ is the matrix of impulse responses at horizon $k$. Sign restrictions are imposed on $m$ variables $(m<n)$ over the horizon $0, \ldots, K$ so that $b_{j}$ identifies the shock of interest. Empirically, given the estimated reduced form VAR, we take $n_{1}$ draws from the posterior of the Normal-Wishart for $(A \Sigma)$ and $n_{2}$ draws from an independent uniform prior to compute the impulse vector $b_{j}$ and the associated impulse responses as described above. To ensure that the retained draws generate all the IRs that satisfy the sign restrictions, each draw for which the IRs do not comply with the sign restrictions are discarded. This procedure is repeated $n_{3}$ times and the error bands are calculated based on the favorable draws. We use $n_{1}=n_{2}=200, n_{3}=1,000$, and $K=3$ for the estimation. 


\section{Endnotes}

${ }^{1}$ Qiao (2005) strongly argues that the exchange rate channel of the wealth effect increases the complexity of forecasting current account movement. His main point relates to the interdependencies between nations via international trade, which make exchange rates endogenous to monetary policies, invalidating elasticity-type models in predicting the effects of exchange rate fluctuations. With a strictly limited capital movement and a less prevalent trade, exchange rate policies can be separated from monetary policies so that when an exogenous exchange rate change takes place, the domestic price level can remain unaffected because the money supply is unaltered. In such conditions, exchange rate depreciation may restore the trade balance and appreciation may increase the trade deficit. But, as economies integrate and liberalize, exchange rate can be considered as a forwardlooking variable and thus reflects people's beliefs about the relative tightness of monetary policy in a country compared to others. In this case, depreciation may or may not lead to a reduction in trade deficit.

2 Some authors identify the savings glut hypothesis (Bernanke, 2005, 2007), fiscal policy (Erceg, Guerrieri, and Gust, 2005; Corsetti and Muller, 2006; Kim and Roubini, 2008; Batdelger and Kandil, 2012), productivity shocks (Bems, Dedola, and Smets, 2007; Corsetti, Dedola, and Leduc, 2008; Bussiere, Fratzscher, and Muller, 2010), as well as stock prices shocks (Berg, 2011, Fratzscher and Straub, 2009; Fratzscher, Juvenal, and Sarno, 2010; Laibson and Mollerstrom, 2010) as the main drivers of the current account imbalances. Others focus on the adjustment mechanism and emphasize that exchange rate depreciation helps to restore current account balances for countries with large external deficits (Krugman, 2007).

3 Recent studies document that financial liberalization has led to a rapid development in housing markets translated into large capital inflows, exchange rate appreciation, credit, and consumption booms (Fedderke and Liu, 2002; Aron, Muellbauer, and Murphy, 2006; Gupta and Ndahiriwe, 2010).

${ }^{4}$ Adam and Kuang (2011) develop a simple open economy asset pricing model that accounts for the house price and the current account dynamics for the $G 7$ economies. They find that the model-implied correlation is greater than the data-generating correlation between the total accumulated current account deficit and the house price growth over the same period. Thus, as reported by Bergin and Sheffrin (2000) and Nason and Rogers (2006), structural models of current account tend to be invalid empirically[0].

5 To empirically test the theoretical superiority of the sign restriction over the recursive ordering, we also include results from the latter.

${ }^{6}$ Details on the implementation are provided in the Appendix.

7 See, for instance, Aron, Muellbauer, and Murphy (2006), Ncube and Ndou (2011), Das, Gupta, and Kanda (2011), Peretti, Gupta, and Inglesi-Lotz (2012), and Simo-Kengne, Gupta, and Bittencourt (2013).

8 This line of thinking was verified based on the BVAR estimates under the Choleski decomposition. Details of these results are available upon request from the authors.

9 These reactions of the macroeconomic variables are also fundamentally different from the responses following technology and fiscal policy shocks. As argued in Fratzscher and Straub (2009), a positive technology shock induces an increase in consumption associated with a fall in inflation. On the other hand, a fiscal policy shock (fall in government spending) results in a positive reaction of private consumption and inflation.

10 The reader is referred to the Appendix for further details.

${ }^{11}$ In the second half of 2003 , mortgage loans comprised $32 \%$ of the total loans and advances on the bank's balance sheets (Luüs, 2005). 
12 Although there are other house price indices available for South Africa, none of them report data starting in 1979:Q1, except for ABSA house price indices, which starts in 1966:Q1. Given that we have an eight-variable VAR with two lags, which in turn, requires a relatively long data span to ensure significant parameter estimates, we decided to use the ABSA database to obtain reliable results. Note that, in this regard (i.e., the choice of the house price data), we follow other researchers who that analyze the housing market of South Africa.

13 See Doan (2009) for computation details.

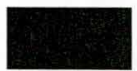

\section{References}

Aastveit, K.A., H.C. Bjørnland, and L.A. Thorsrud. What Drives Oil Prices? Emerging versus Developed Economies. Norwegian Business School, CAMP Working Paper No. 2/2012, 2012.

Adam, K. and P. Kuang. House Price Booms and the Current Account. NBER Macroeconomics Annual, 2011, 26, 77-122.

Aizenman, J. and Y. Jinjarak. Current Account Patterns and National Real Estate Markets. National Bureau of Economic Research Working Paper No. 13921, 2008.

Andre, C., R. Gupta, and P.T. Kanda. Do House Prices Impact Consumption and Interest Rate? Evidence from OECD Countries Using an Agnostic Identification Procedure. Applied Economics Quarterly, 2012, 58:1, 19-70.

Aron, J., J. Muellbauer, and A. Murphy. Housing Wealth, Credit Conditions and Consumption. MPRA Paper No. 24485, 2006.

Aspachs-Bracons, O. and P. Rabanal. The Effects of Housing Prices and Monetary Policy in a Currency Union. International Journal of Central Banking, 2011, 7:1, 225-74.

Batdelger, T. and M. Kandil. Determinants of the Current Account Balance in the United States. Applied Economics, 2012, 44, 653-69.

Bems, R., L. Dedola, and F. Smets. U.S. Imbalances: The Role of Technology and Policy. Journal of International Money and Finance, 2007, 26, 523-45.

Berg, T.O. Cross-country Evidence on the Relation between Stock Prices and the Current Account. Applied Economics, 2011, 45:16, 2266-77.

Bergin, P. Asset Price Booms and Current Account Deficits. FRBSF Economic Letter, December 5, 2011, 1-4.

Bergin, P.R. and S. Sheffrin. Interest Rates, Exchanges Rates and the Present Value Models of the Current Account. Economic Journal, 2000, 110, 535-58.

Bernanke, B.S. The Global Saving Glut and the U.S. Current Account Deficit. Speech, Bundesbank Lecture. Berlin, Germany, September, 11, 2005.

—. Global Imbalances: Recent Developments and Prospects. Sandridge Lecture, Virginia Association of Economics. Richmond, Virginia, March 10, 2007.

Buissiere, M., M. Fratzscher, and G.J. Muller. Productivity Shocks, Budget Deficits and the Current Account. Journal of International Money and Finance, 2010, 29, 1562-79.

Busch, U., M. Scharnagl, and J. Scheithauer. Loan Supply in Germany during the Financial Crisis. Economic Studies Discussion Paper, Series 1, No. 05/2010, 2010.

Corsetti, G., L. Dedola, and S. Leduc. Productivity, External Balance and Exchange Rates: Evidence on the Transmission Mechanism among G-7 Countries. National Bureau of Economic Research, 2008, 117-94. 
Corsetti, G. and G.J. Muller. Twin Deficits: Squaring Theory, Evidence and Common Sense. Economic Policy, 2006, 48, 597-638.

Das, S., R. Gupta, and P.T. Kanda. Bubbles in South African House Prices and their Impact on Consumption. Journal of Real Estate Literature, 2011, 19:1, 71-91.

Doan, T. Understanding the Historical Decomposition. Estima Forum, 2009. Available at: http: //www.estima.com/forum/viewtopic.php?f $=4 \& \mathrm{t}=306$.

Erceg, C.J., L. Guerrieri, and C. Gust. Expansionary Fiscal Shocks and the U.S. Trade Deficit. International Finance, 2005, 8, 363-97.

Engel, C. and J.H. Rogers. The U.S. Current Account Deficit and the Expected Share of World Output. Journal of Monetary Economics, 2006, 53, 1063-93.

Fedderke, J.W. and W. Liu. Modelling the Determinants of Capital Flows and Capital Flight: with an Application to South African Data from 1960 to 1995. Economic Modelling, 2002, 19, 419-44.

Finicelli, A. House Price Developments and Fundamentals in the United States. Bank of Italy Occasional Paper No. 7, 2007.

Fratzscher, M., L. Juvenal, and L. Sarno. Asset Prices, Exchange Rates and the Current Account. European Economic Review, 2010, 54, 643-58.

Fratzscher, M. and R. Straub. Asset Prices and Current Account Fluctuations in G-7 Economies. IMF Staff Papers, 2009, 56, 633-54.

Fry, R. and A. Pagan. Sign Restrictions in Structural Vector Autoregressions: A Critical Review. Journal of Economic Literature, 2011, 49:4, 938-60.

Gavin, M. The Stock Market and Exchange Rate Dynamics. Journal of International Money and Finance, 1989, 8:2, 181-200.

Gete, P. Housing Markets and Current Account Dynamics. Georgetown University Working Paper, 2010.

Gupta, R. and K. Ndahiriwe. Financial Liberalization and the Effectiveness of Monetary Policy on House Prices in South Africa. The IUP Journal of Monetary Economics, 2010, 8:4, 59-74. Gupta, R. and F. Hartley. The Role of Asset Prices in Forecasting Inflation and Output in South Africa. Journal of Emerging Market Finance, 2013, 12:3, 239-91.

Gupta, R. and R. Inglezi-Lotz. Relationship between House Prices and Inflation in South Africa. International Journal of Strategic Property Management, forthcoming.

Hau, H. Real Exchange Rate Volatility and Economic Openness: Theory and Evidence. Journal of Money, Credit and Banking, 2002, 34:3, 611-30.

Iacoviello, M. and S. Neri. Housing Market Spillovers: Evidence from an Estimated DSGE Model. American Economic Journal: Macroeconomics, 2010, 2, 125-64.

Jarocinski, M. and F. Smets. House Prices and the Stance of Monetary Policy. European Central Bank Working Paper 891, 2008.

Kandiero, T. Current Account Situation in South Africa: Issues to Consider. African Development Bank Economic Research Working Paper No. 90, 2007.

Kim, S. and N. Roubini. Twin Deficit or Twin Divergence? Fiscal Policy, Current Account and Real Exchange Rate in the U.S. Journal of International Economics, 2008, 74, 362-83.

Kole, L. and R.F. Martin. The Relationship between House Prices and the Current Account. 2009. Available at: http://e-perspectives.com/institute/events/09sciea_kole.pdf.

Kraay, A. and J. Ventura. The Dot-com Bubble, the Bush Deficits and the U.S. Current Account. In G-7 Current Account Imbalances: Sustainability and Adjustment. National Bureau of Economic Research Working Paper No. 11543, 2005. 
Krugman, P. Will there be a Dollar Crisis? Economic Policy, 2007, 22, 435-67.

Laibson, D. and J. Mollerstrom. Capital Flows, Consumption Booms and Asset Bubbles: A Behavioural Alternative to the Savings Glut Hypothesis. The Economic Journal, 2010, 120, 354-74.

Luüs, C. The Absa Residential Property Market Database for South Africa-Key Data Trends and Implications. BIS Paper, 2005, 21, 149-70.

McKinnon, R.I. The Exchange Rate and the Trade Balance: Insular versus Open Economies. Open Economies Review, 1990, 1, 17-37.

McKinnon, R.I. and K. Ohno. Dollar and Yen: Resolving Economic Conflict between the United States and Japan. Cambridge, MA: MIT Press, 1997.

Musso, A., S. Neri, and L. Stracca. Housing, Consumption and Monetary Policy: How Different are the U.S. and the Euro Area? Journal of Banking and Finance, 2011, 35:11, 3019-41.

Naraidoo, R. and K. Ndahiriwe. Financial Asset Prices, Linear and Nonlinear Policy. An Insample Assessment of the Reaction Function of the South African Reserve Bank. Journal of Economic Studies, 2012, 39:2, 161-77.

Naraidoo, R and L. Raputsoane. Zone-targeting Monetary Policy Preferences and Financial Market Conditions: A Flexible Non-Linear Policy Reaction Function of the SARB Monetary Policy. South African Journal of Economics, 2010, 78:4, 400-17.

Nason, J.M. and J.H. Rogers. The Present Value Model of the Current Account has been Rejected: Round up the Usual Suspects. Journal of International Economics, 2000, 68:1, 159-87.

Ncube, M. and E. Ndou. Monetary Policy Transmission, House Prices and Consumer Spending in South Africa: An SVAR Approach. African Development Bank Group Working Paper No 133, 2011.

Paustian, M. Assessing Sign Restrictions. The B.E. Journal of Macroeconomics, 2007, 7:1, 133.

Peretti, V., R. Gupta, and R. Inglesi-Lotz. Do House Prices Impact Consumption and Interest Rate in South Africa? Evidence from a Time-Varying Vector Autoregressive Model. Economics, Financial Markets and Management, 2012, 7:4, 25-45.

Punzi, M.T. The Link between Housing Prices and Current Account Deficit: A Study of 10 OECD Countries. 2007, Available at: http://merlin.fae.ua.es/punzi/Panel_Var.pdf.

Qiao, H. Exchange Rates and Trade Balances under the Dollar Standard. Stanford University Working Paper No. 259, 2005.

Schiller, R.J. Low Interest Rate and High Asset Prices: An Interpretation in Terms of Changing Popular Economic Models. National Bureau of Economic Research Working Paper No. 13761, 2007.

Sims, C.A. Policy Analysis with Econometric Models. Brookings Papers on Economic Activity, 1982, 2, 107-52.

Sims, C.A., J. Stock, and M.W. Watson. Inference in Linear Time Series Models with Some Unit Roots. Econometrica, 1990, 58, 113-44.

Simo-Kengne, B.D., R. Gupta, and M. Bittencourt. The Impact of House Prices on Consumption in South Africa: Evidence from Provincial-Level Panel VARs. Housing Studies, 2013, 28:8, 1133-54.

Smit, B. The South African Current Account in the Context of SA Macroeconomic Policy Challenges. Paper presented at the South African Reserve Bank Conference, 2006.

Uhlig, H. What Are the Effects of Monetary Policy on Output? Results from an Agnostic Identification Procedure. Journal of Monetary Economics, 2005, 52, 381-419. 
Yang, L. and H. Zhiqiang. On Correlation between RMB Exchange Rate and Real Estate Price Based on Financial Engineering. Systems Engineering Procedia, 2012, 3, 146-52.

We would like to thank an anonymous referee for many belpful comments.

Beatrice D. Simo-Kengne, University of Pretoria, Pretoria, 0002, South Africa or simobeatrice@gmail.com

Rangan Gupta, University of Pretoria, Pretoria, 0002, South Africa or rangan.gupta@ up.ac.za.

Goodness C. Aye, University of Pretoria, Pretoria, 0002, South Africa or goodness.aye@ up.ac.za. 
Copyright of Journal of Housing Research is the property of American Real Estate Society and its content may not be copied or emailed to multiple sites or posted to a listserv without the copyright holder's express written permission. However, users may print, download, or email articles for individual use. 